\title{
Parental Involvement and Pupils' Academic Performance in the Cape Coast Metropolis, Ghana
}

https://doi.org/10.1515/edu-2020-0142

received March 22, 2020; accepted January 31, 2021.

\begin{abstract}
Studies have shown that pupils' academic performance is not only determined by their parents' socio-economic status but also parental involvement in the education processes. The study, therefore, examined the socio-economic status of parents and its influence on pupils' academic performance looking at the role of parental involvement in that relationship. With Walberg's theory of educational productivity as a lens, the findings were based on surveys with 120 pupils selected randomly from Kwaprow Basic School and 10 and 5 interviews with parents and teachers respectively. The study found that parents' education did not significantly affect students' academic performance. Parents were not assisting their children in their academic activities including failure to attend Parent-Teacher Association meetings and not assisting them with homework. This was largely attributed to parental low educational level. However, with a $0.045,0.028,0.041$ and 0.036 , as p-values, the study showed that there was a statistically significant relationship between parental involvement, occupation and family size and academic performance of pupils. In order to improve students' academic performance, the study recommended that the Parent-Teacher Associations (PTA) should intensively sensitise parents on the need to involve themselves in their wards' education so as to aid them to perform better academically.
\end{abstract}

Keywords: parental involvement, pupils, academic performance, socio-economic status

\footnotetext{
*Corresponding author: Daniel Ampem Darko-Asumadu, Department of Sociology \& Anthropology; University of Cape Coast, Ghana, E-mail: ddanielampem87@gmail.com

Solomon Sika-Bright, Department of Sociology \& Anthropology; University of Cape Coast, Cape Coast, Ghana
}

\section{Introduction}

Basic education, which constitutes educating children at the primary and lower secondary levels, is important for child development. This is because it exposes the child to ideas and knowledge which serves as a foundation on which to build further education (Akanle, 2007). It is therefore important to ensure that every child has access to basic education. The United Nations International Children's Emergency Fund [UNICEF] (2014) has echoed that access to education is more than a fundamental human right for every child. It paves the way to a successful and productive future of the child (UNICEF, 2014). In support of UNICEF's agenda, the Sustainable Development Goal 4 was set to ensure inclusive and equitable quality education and promote lifelong learning opportunities for all by 2030 (United Nations, 2006). One of its targets is to ensure that there are no disparities in education and ensure equal access to all levels of education and vocational training for the vulnerable, including persons with disabilities, indigenous peoples and children in vulnerable situations.

This agenda has however been undermined by the pervasive poverty in many developed and developing countries. The United States Department of Education (2000) observed that poverty is an important factor accounting for differences in performance across the sub-urban and sub-districts. Nevertheless, poverty has not been the only reason that has accounted for the differences in performance of students. The socioeconomic background of parents, as indicated by McNeal (2001), has overridden other educational influences such as parental involvement. According to Eamon (2005), academic performances of students depended on many factors including socio- economic status of parents. In the United States of America, Barry (2005) argued that students with higher socio-economic status had higher test scores than those with lower socio-economic status. Shah, Atta, Qureshi and Shah (2012) also commented on the roles family economic status played in the lives of students in Pakistan. They argued that family economic status significantly influenced student learning. Also, 
Brown et al. (2020) admonished that students and parents are important stakeholders who should be consulted in the decision-making process; therefore, considered central in the evaluation of the school's performance and future direction.

In most African countries, the socio-economic background of parents tends to affect the academic performance of students. In some Kenyan communities, Orodho (2013) stressed that academic achievement was undermined by parents' socio-economic status and political factors. This was further cemented by Nadenge (2015) who stated that parents' socio-economic background influenced the academic performance of students in Nairobi.

In Ghana, some scholars have conducted research on socio-economic status and academic performance. In the study by Adane (2013) on the factors that account for low academic performance in Kemp Methodist Junior High School in Aburi, Eastern Region of Ghana, she identified school environmental factors, home conditions, teacher factors, and pupils' characteristics as significantly affecting pupils' academic performance. Subsequently, Mensah (2013) investigated the socioeconomic background of students in Saint Monica College of Education and the results of the study showed that parents' educational level, occupation and income levels had an impact on the academic performance of students.

Based on the studies stated above, it can be seen that, over the years, various studies concerning the factors that influence the academic performance of the students have been conducted. Most of the studies have also looked at the effects of socio-economic status of parents on the academic performance of students but little has been done on the mediating roles of parental involvement in these dynamics which is the thrust of the current study.

Parental involvement in these dynamics can be explained using Walberg's theory of educational productivity. Walberg's (1981) theory of educational productivity identified categories of factors that influenced learning outcomes and achievements. Walberg's theory is based on the assumption that academic performance of students depends on socio-emotional influences, parental support often determined by their social and economic status, student-teacher interaction, peer groups, school culture and classroom climate (Greenberg et al., 2003). This theory provides the understanding of various forms of parental support (economic, social and involvement) and other characteristics which may influence the students' academic performance in Kwaprow Basic School. This theory plays a fundamental role in its application to this topic on various factors that promote students' academic performance in schools.

\subsection{Objectives of the study}

1. Examine the influence of parents' occupation on the academic performance of students in Kwaprow Basic School.

2. Examine the influence one's family size has on his or her academic performance in Kwaprow Basic School

3. Determine how parents' level of education affect students' academic performance in Kwaprow Basic School.

4. Determine how parental involvement affects the academic performance of students of Kwaprow Basic School.

\subsection{Research Question}

1. How does parents' occupation influence the academic performance of students in Kwaprow Basic School?

2. How does family size affect the academic performance of students in Kwaprow Basic School?

3. How does parents' level of education influence the academic performance of students in Kwaprow Basic School?

4. How does parental involvement affect the academic performance of students in Kwaprow Basic School?

\section{Literature Review}

The section reviews literature according to the objectives of the study. It begins with parental involvement, their level of education, occupation and family size and how they affect students' academic performance.

\subsection{Parental Involvement and Students' Academic Performance}

Parental involvement is defined as having an awareness of and involvement in school work, understanding of the interaction between parenting skills and the student success in schooling, and a commitment to students (Nadenge, 2015). Parental involvement could be in two forms, home based and school based. Home-based parental involvement includes helping students with homework, talking with them about school, expressing 
high expectations, encouraging school success, and providing structures that are conducive for learning (Altschul, 2012). School-based parental involvement on the other hand includes volunteering at school, participating in school events and school organizations as well as communicating with teachers and school staff.

Nadenge (2015) established a significant positive correlation between good parent-teacher relationship and parents' involvement in their children's and academic achievement. Students felt that when their parents are involved in their education, they guide them in making the right choices in career as well as in discipline (Nadenge, 2015). This also yielded positive results. It was found that parental involvement has significance effect in better academic performance of their children. Juma (2016) reported a very strong positive correlation between parental involvement in education and students' academic performance. Epstein, Sanders, Simon and Salinas (2002) discussed parental involvement as an educational tool needed to achieve academic success. Oslen and Fuller (2010) stated that children consistently completing their homework is a benefit children gain from parental involvement in their education.

\subsection{Parental Level of Education and Students' Educational Performance}

Parental level of education is a decisive factor in the educational attainment of their children (Mensah, 2013). Parents' level of education is important to schooling as parents want their children to maintain the status quo (Mallan, 2009). The educational background on the other hand basically means the type of education acquired by an individual; it can be western or religious depending on the environment and geographical location. Nannyonjo (2007) makes some analysis to prove that students whose parents had some level of education tend to perform better academically. He compared the performance of students whose parents did not finish primary school and those who finished senior four or senior six or university and found that the latter performed considerably better.

Okumu, Nakajjo and Isoke (2008), in a study of socio-economic determinants of second cycle schools, found that high academic attainment of a mother and father significantly reduces chances of second cycle school dropout for students in rural and urban areas. For a mother, this phenomenon could be attributed to the fact that educated mothers reduce the time spent doing household chores while increasing the time spent with their children than their uneducated counterparts.
Beller (2008) points out that there is a strong intergenerational correlation in education. The quantity and quality of time devoted by parents to their children is positively related to the parents' education status. Students with families where parents have less education tend to systematically perform worse than students whose parents have more education (Mensah, 2013). In families where parents experience difficulties in reading and writing, there is a danger that low literacy is passed on to the next generation (Cooter, 2006).

\subsection{Parental Occupation on Children's Academic Performance}

Parental occupation has a significant effect on children's academic achievement as well as their welfare. Good parental occupation has a positive effect on the academic achievement of students. On the other hand, possessing a job also reduces the time available for parents to spend with their children and to involve themselves in their life at school. Research conducted by Hassan (2009) indicated that there is a relationship between parental occupational status and academic performance of their wards. According to Kalil (2005), high occupational status people have more resources to meet the needs of their homes, while the low occupational status people have limited resources for the same.

Parents with higher occupational status and educational attainment may also have higher aspirations and expectations for their children's occupation and education, which in turn can influence their commitment to learning (Afful, 2014). Juma (2016) concluded that there is a significant positive correlation between parents' occupation and students' academic performance. According to a study conducted by Okwan (2014), children of parents who belong to the "skilled" type of occupation such as teaching, nursing, banking and the likes proved to perform better academically than their peers whose parents' occupations were "unskilled" such as petty trading, subsistent farming and day-labourers at building sites, wood and cocoa loading sites. Thus, students whose parents are in good formal employment exhibit higher academic attainments than those whose parents practice nomadic, peasantry or are unemployed.

Mudassir and Abubakar (2015) conducted a study on the impact of parents' occupation on academic performance of secondary school students in Malaysia. The result showed that students from parents with formal occupation perform better than those from parents with informal education. Graetz (2006) opined that parents 
in unskilled occupations earn lower incomes and often have to work longer hours to earn more for their families. Muhammed (2012) conducted a study on the impact of parents' profession on their children's learning English in Pakistan. The results revealed that for learning English, the parents' profession has a positive correlation on it that varies with respect to their professions. Parents said that their occupation determined whether they had enough time with their children and get involved in their learning or be able to pay their fees and provide for other needs (Nadenge, 2015). Reeves (2009) asserts that the economic activities of parents may create problems for day students arising from a lot of work at home.

\subsection{Family Size and Academic Performance of Children}

Family size has been found to play an important role in student's academic Performance (Afful, 2014). According to Chen and Liu (2014), family size has a measurable effect on academic outcomes. They further explained that a family's overall mental maturity level, undivided resources, as well as heightened parental responsiveness and care will all assist children in small-size families in their schooling. The decreasing benefits of family resources on academic performance are rather experienced by children of large family-sizes (Chen \& Liu, 2014).

Lacovou (2001) revealed that children from larger families are found to do worse than children from smaller families. He also found out that children lower down the birth order do worse than those higher up the birth order (Lacovou, 2001). Parents usually accord more attention and time to the first born (Seigal \& McCoach, 2007). Lacovou (2001) stated that attention given to children by parents declines as the number of siblings increases and later born children perform less well than earlier born siblings.

Rouse and Barrows (2006) indicated that the smaller a family structure is, the more success is recorded by the children as regards the academic pursuit. The reason for this is that more concentration is given by parents to fewer children than the families where the children are many. Thus, students from smaller families tend to perform better than those from larger families (Mensah, 2013). Amazu and Okoro (2015) also showed that family size, in terms of the number of children in the household, has a significant influence on the academic performance of students in the study area, Aba educational zone. Thus, the more children there are in the family the less the inputs accruing to each child. These key inputs are not usually money; other essential things such as time and attention are key to improved academic attainment by the children.

The negative relationship between family size and educational achievements typically found in literature is however not necessarily proof of a negative effect of the number of children. The number of children is a choice variable of the parents and it might be that certain characteristics of parents, such as their educational attainments, affect both the number of children as well as the educational attainments of those children. This can cause a negative correlation between the number of siblings and future educational achievement, even if no causal effect of the number of siblings exists.

\section{Methodology}

The study was conducted in Kwaprow Basic School, located in the Cape Coast Metropolis in the Central Region of Ghana. The school comprises 300 pupils, 20 teachers and one head master. Kwaprow Basic School, located at one of the satellite communities of University of Cape Coast, has indigenes with low socio-economic status, which has consequences for parental involvement. It was therefore purposively selected as the study site so as to understand the effects of parental involvement on pupils' academic performance.

The study adopted a descriptive research design employing a concurrent mixed method. The researchers selected this design because it described how social, economic status and involvement of parents affect student's academic performance. This design described the relationship between parent and the wards and how that translated into student's academic performance. Essentially the design allowed us to place parents' socioeconomic status as well as their involvement in their children's academic affairs.

The population for the study comprised students in Kwaprow Basic School. Students were involved because they are directly affected by parental socio-economic background and involvement. The total number of students in the Kwaprow JHS was 258. The population comprised students from high and low academic performance level. A sample of 120 students was selected from the population. The sample included male and female students in the first, second and third year in the Junior High School.

The study relied on primary data with questionnaires and interviews as research instruments. The questionnaire was developed for this research to get responses and 
views from students. The questionnaires employed both opened and closed ended questions. An interview guide was used to elicit responses from parents and teachers. These instruments were pre-tested at Amamoma Basic School at ensure their validity. The survey instrument was also tested for reliability at a Cronbach alpha of 0.79.

The gathered data were coded, edited and analysed using the Statistical Product for Service Solution software version 21. We used descriptive and inferential statistics such as frequency tables, percentages, cross tabulation, chi-square test and Pearson correlation coefficient to establish the relationship between socio-economic status of parents: mediating role of parental involvement. Responses gathered from the interviews were transcribed and analysed using narrative analysis to complement the quantitative data.

\section{Results and Discussion}

\subsection{Background Characteristics of Respondents}

This section presents the background information of the respondents. The background of the pupils is in relation to class levels, gender, age and number of siblings.

The study revealed that 60 percent of the pupils were females. This implied that the majority of pupils from JHS 1 to 3 were females. The age of pupils showed that the majority (55.8\%) fell within the age bracket of 13-15 years. This confirms the Ministry of Education's (2013) report that, in Ghana, the minimum age required to be enrolled in the Junior High School is between 12-15 years. In terms of the class of pupils, the data distribution showed that 40 percent of the pupils were in JHS1, 25(20.8\%) were in JHS2 and 47(39.2\%) were in JHS 3. The majority of pupils $(56.7 \%)$ had an average of five siblings.

\subsection{Pupils' Academic Performance}

The study assessed the academic performance of the pupils using subjective indicators such as "I pass all my subjects", "I do well in my end of term exams", "I have repeated before because I did not do well in the exams", "I am always prepared for exams", "I understand what the teacher teaches which lead to high class scores", "I do well with my class exercises" and "I do well with my homework". Pupils were asked to indicate a "Yes" or "No" response to the following statements. The results are
Table 1: Socio-Demographic Characteristics of Respondents.

\begin{tabular}{lll}
\hline Socio-Demographics & Frequency $(\mathbf{n = 1 2 0})$ & Percent \\
\hline Class & & \\
JHS 1 & 48 & 40 \\
JHS 2 & 25 & 20.8 \\
JHS 3 & 47 & 39.2 \\
Gender & & \\
Male & 48 & 40.0 \\
Female & 72 & 60.0 \\
Age(years) & & \\
12 and below & 29 & 24.2 \\
13-15 & 67 & 55.8 \\
16 and above & 24 & 20.0 \\
Number of Siblings & & \\
1-3 & 32 & 21.7 \\
$4-6$ & 68 & 56.7 \\
7 and above & 20 & 16.7 \\
\hline
\end{tabular}

Source: Fieldwork, Darko-Asumadu and Sika-Bright (2019)

presented in Table 2. The average mean was compared to the individual means for each indicator. When the average mean was higher than the individual means, it can be deduced that their academic performance was below the average. In a similar vein, when the average mean was lower than the individual means, it can be inferred that their academic performance was above the average.

Comparing the means of each indicator of academic performance to the average mean in Table 2, the study found that pupils at Kwaprow Basic School did well in class exercises and homework. In addition, the majority of pupils were always prepared for exams and had not repeated in class before. However, the average mean exceeded the means of passing all the subjects, understanding what is taught in class and doing well in the end of term exams. This finding implied that although, pupils partook in class exercises and homework, prepared well for exams, their end of semester examination results did not exceed the average. In all, pupils did extremely well in class exercises and homework as compared to the others. Unfortunately, their performance in the end of term examination was below the average.

\subsection{Parental Socio-Economic Status and Parental Involvement}

This section discusses the relationship that exists between parental socio-economic status and the academic performance of pupils. It looks at various socio-economic 
Table 2: Academic Performance of Pupils.

\begin{tabular}{|c|c|c|c|c|}
\hline Academic performance & & Frequency $(n=120)$ & Percent & Mean \\
\hline \multirow[t]{2}{*}{ I pass all my subjects } & Yes & 86 & 71.7 & 1.71 \\
\hline & No & 34 & 28.3 & \\
\hline \multirow[t]{2}{*}{ I do well in my end of term exams } & Yes & 77 & 64.2 & 1.70 \\
\hline & No & 43 & 35.8 & \\
\hline \multirow[t]{2}{*}{ I have not repeated in class before } & Yes & 95 & 79.2 & 1.79 \\
\hline & No & 25 & 20.8 & \\
\hline \multirow[t]{2}{*}{ I am always prepared for exams } & Yes & 96 & 80 & 1.80 \\
\hline & No & 24 & 20 & \\
\hline \multirow[t]{2}{*}{ I understand what is taught in class } & Yes & 77 & 64.2 & 1.64 \\
\hline & No & 43 & 35.8 & \\
\hline \multirow[t]{2}{*}{ I do well in class exercise } & Yes & 97 & 80.8 & 1.81 \\
\hline & No & 23 & 19.2 & \\
\hline \multirow[t]{2}{*}{ I do well in homework } & Yes & 96 & 80 & 1.80 \\
\hline & No & 24 & 20 & \\
\hline Average Mean & & & & 1.75 \\
\hline
\end{tabular}

Source: Fieldwork, Darko-Asumadu and Sika-Bright (2019)

variables such as parental occupation, parental education and family size as well as pupils' academic performance. It further illustrates the role of parental involvement in pupils' academic performance.

\subsection{Parental Occupation}

This objective was to determine the extent to which parental occupation influenced the academic performance of pupils. The section begins with the activities parents are involved in and subsequently discusses the relationship between their occupation and pupils' academic activities.

The study revealed that $111(92.5 \%)$ mothers were tertiary (service) sector workers as compared to those in the primary sector. Approximately $77(64 \%)$ percent of the fathers worked within the primary sector (production) as farmers. This finding supported the 2015 Ghana Statistical Service's Labour Force Report which posited that a larger number of females provided services in a form of trading. Also, a larger proportion of the fathers (14.2\%) in Kwaprow were found in the primary sector compared to the mothers (5\%). This finding also avers the Ghana Statistical Service's (2015) Labour Force Report which stipulated that the primary and farming sector is dominated by males as compared to females. To gather more information on parents' occupation and academic performance, the study sought to further explore the dynamics between these variables by seeking responses from pupils. This is shown in Table 2.

From Table 3, the majority of pupils (53.3\%) indicated that their parents finish work early to attend to their needs. Also, 34.2 percent of the pupils said their parent's occupation allowed them to get time for them. The majority of pupils indicated that their parents go to work every day. 43.3 percent of pupils asserted that their parents spend enough time with them at home. However, another 87.5 percent assisted their parents with household responsibilities. Furthermore, 49.2 percent said they work before going to school.

Bakken (2003) pointed out that parents who possess a job have reduced time to spend with their children. This finding contradicts our finding from the pupils. This is because most of the parents who are in the tertiary field are cleaners, security men, traders and so they finished work early due to the flexibility in their work. The majority of pupils said they assisted their parents with household work before going to school. Out of this, 34 were females and 25 were males. This is similar to the study by Scharrf and Brady (2006) who argued that girls are expected to 
Table 3: Parental Occupation.

\begin{tabular}{|c|c|c|c|c|}
\hline Statements & $\begin{array}{l}\text { No } \\
(n=120, \%)\end{array}$ & $\begin{array}{l}\text { Sometimes } \\
(n=120, \%)\end{array}$ & $\begin{array}{l}\text { Yes } \\
(n=120, \%)\end{array}$ & Mean \\
\hline My parents finish work early to attend to my need & $21(2.4)$ & $35(29.2)$ & $64(53.3)$ & 2.35 \\
\hline My parents work allows them to get time for me & $39(32.5)$ & $40(33.3)$ & $41(34.2)$ & 2.02 \\
\hline My parents go to work everyday & $15(14.2)$ & $25(20.8)$ & $78(65.0)$ & 2.48 \\
\hline My parents spend enough time with me at home & 23(19.2) & $45(37.5)$ & $52(43.3)$ & 2.23 \\
\hline I help my parents to work at home & $5(4.1)$ & $10(8.3)$ & $105(87.5)$ & 2.83 \\
\hline My parents let me work before I go to school & $28(23.3)$ & $33(27.5)$ & $59(49.2)$ & 2.26 \\
\hline Average Mean & & & & 2.36 \\
\hline
\end{tabular}

Source: Fieldwork, Darko-Asumadu and Sika-Bright (2019)

help their parents with house chores before going to school and therefore arrive to class late and exhausted.

\subsection{Relationship between Parent Occupation and Academic Performance}

The occupation of parents included teaching, farming, business and trading. Following the findings on the academic performance of pupils, doing well in homework, which was the second highest mean score, was employed to assess its relationship with the occupation of parents.

The majority of mothers were into trading while fathers were into farming. In the findings displayed, $81(80.2 \%)$ out of 97 pupils whose mothers were into trading asserted that they did well with homework. The same can be said for the 61(79.2\%) out of the 97 pupils whose fathers were into farming. It can also be deduced that there is a significant difference in the mothers' and fathers' occupation and the performance with homework of the pupils. The chi-square values of 0.041 and 0.036 depicted that the occupation of parents played a role in guiding their children with homework. Similarly, the roles parents played in their children's homework also differed across their occupations. Children whose mothers were traders performed better with their homework than those whose mothers were teachers and unemployed; this finding contradicting with Okwan's (2014) assertion that students whose parents are in good formal employment exhibit higher academic attainments than those whose parents practice nomadic, peasantry or are nonemployed. Similarly, the study diverges from Mudassir and Abubakar's (2015) view that students from parents with formal occupation perform better than those from parents with informal education.
The mean scores of 2.48 and 2.83 exceeds the average mean score of 2.36 (see Table 3 ). The highest mean of 2.83 indicates that the majority of pupils said they indeed help their parents to work at home. Most of the parents said their occupation does not affect the time they get for their children. Some parents were asked how the amount of time they spend at work affects their involvement in education of their children. These were their responses:

I do not go to work always but I am also a farmer. My occupation gives me enough time to concentrate on my children's academic performance because I don't spend much time at work since the nature of my work doesn't permit me to. (A 51-year-old parent)

I sell rice. The nature of my occupation gives me enough time to concentrate on my children's academic performance. This is because I work on two shifts morning and evening. (A 34-year-old parent)

Also, some teachers were asked of their view on how parents' occupation affect the academic performance of pupils. Most of the teachers said the occupation of the parents negatively affected the academic performance of their pupils.

For our school, I think is negatively affecting their performance. Our kids, some of them have all that it takes to perform but they don't. One thing that I can link to this is the occupation of the parents. They engage the students so much. You will see them just after school at science selling, doing all sorts of menial jobs and majority of them are into that so it negatively affects the performance of the students. (A 32-year-old teacher)

It can be deduced that the occupation of parents allowed them to get time for the children. The interview from the teachers contradicts with that of the parents and 
Table 4: Parent Occupation and Homework of Pupils.

\begin{tabular}{|c|c|c|c|c|}
\hline Occupation & Homework & & Total & $p$-value \\
\hline & No & Yes & & \\
\hline & $n(\%)$ & $\mathrm{n}(\%)$ & $\mathrm{N}(\%)$ & \\
\hline Mother's Occupation & & & & 0.041 \\
\hline Teaching & $3(30)$ & $7(70)$ & $10(100)$ & \\
\hline Farming & $0(0)$ & $5(100)$ & $5(100)$ & \\
\hline Trading & $20(19.8)$ & $81(80.2)$ & 101(100) & \\
\hline Unemployed & $0(0)$ & $4(100)$ & $4(100)$ & \\
\hline Total & 23(19.2) & $97(80.8)$ & $100(100)$ & \\
\hline Father's Occupation & & & & 0.036 \\
\hline Businessman & $3(14.3)$ & $18(85.7)$ & $21(100)$ & \\
\hline Teaching & 4(19) & $17(81)$ & $21(100)$ & \\
\hline Farming & $16(20.8)$ & 61(79.2) & $77(100)$ & \\
\hline Unemployed & $0(0)$ & $1(100)$ & $1(100)$ & \\
\hline Total & $23(19.2)$ & $97(80.8)$ & $100(100)$ & \\
\hline
\end{tabular}

Source: Fieldwork, Darko-Asumadu and Sika-Bright (2019)

Table 5: Parents Level of Education.

\begin{tabular}{lll}
\hline Level & Frequency $(\mathbf{n = 1 2 0})$ & Percent \\
\hline No education & 37 & 30.8 \\
Basic education & 51 & 42.5 \\
Secondary & 23 & 19.2 \\
Tertiary & 9 & 7.5 \\
\hline
\end{tabular}

Source: Fieldwork, Darko-Asumadu and Sika-Bright (2019)

the pupils. The teachers were of the view that nature of parents' work did not give them enough time to attend to their children. The results from the teachers agree to the findings of Bakken (2003) which reveals that parents possessing jobs have reduced time for their children.

\subsection{Parents' Level of Education}

Parents' level of education is an important factor that influence the performance of children (Mensah, 2013). In this regard, the study asked the pupils to indicate whether their parents had received formal education and if that was the case, at what level did they reach ahead of the influence of the parent's level of education on pupils' academic performance. This presented in the Table 5.
The study found that $37(30.8 \%)$ of the parents had no formal education where $83(69.2 \%)$ had received formal education. With respect to parents who had received formal education, most of them (42.5\%) completed the basic level, 19.2 percent finished the secondary level while 7.5 percent completed the tertiary level. It can therefore be deduced that, although the majority of the parents had received formal education, few of them completed the tertiary level.

The study further conducted a chi-square test to determine whether the parents' educational status influenced the performance of pupils in Kwaprow Basic as shown in Table 5. Since their performance in the end of term examination was below average, it was measured against parental educational status to find out whether their parents' education influenced their academic performance. This was done to establish whether there is a statistically significant difference between parents with no formal education and the performance of pupils.

The association between parents' education and the academic performance of pupils showed that 68.4 percent of pupils whose parents had received formal education performed well at the end of term examination as compared to 31.6 percent of pupils whose parents had no formal education. Based on the descriptive data distribution, one is likely to make such a conclusion but the chi-square value of 0.730 implied that there is no 
Table 6: Education and End of Term Examination.

\begin{tabular}{|c|c|c|c|c|}
\hline \multirow[t]{2}{*}{ Educational status } & \multicolumn{2}{|c|}{ End of term examination } & \multirow[t]{2}{*}{ Total } & \multirow[t]{2}{*}{$p$-value } \\
\hline & No & Yes & & \\
\hline & $n(\%)$ & $n(\%)$ & $\mathrm{N}(\%)$ & 0.730 \\
\hline No formal education & $7(28)$ & $30(31.6)$ & $37(100)$ & \\
\hline Formal education & $18(72)$ & $65(68.4)$ & $83(100)$ & \\
\hline Total & $25(100)$ & $95(100)$ & $120(100)$ & \\
\hline
\end{tabular}

Source: Fieldwork, Darko-Asumadu and Sika-Bright (2019)

statistically significant difference between the performance of pupils from educated homes and those in non-educated homes. That is, the performance, in terms of their end of term examination, of pupils whose parents had formal education did not differ from those whose parent had not received formal education. The finding of the study showed that pupils' academic performance in Kwaprow Basic School is independent on their parents' educational status. This contradicts Nannyonjo's (2007) analysis that students whose parents had some level of education tend to perform better academically than to whose parents had no education. Again, Walberg's theory of educational productivity that posits that educated parents can influence the academic success of their children diverges from the association between parents' education and pupils' academic performance. More so, this study opposes the view that parents' educational level affects the academic performance of the pupils (Marzano, 2003).

Most of the parents interviewed said they saw education as relevant; in effect placing a high value on educating their children. These are some of the responses:

It is very important. I encourage them to learn hard because education is their future. (A 31-year-old parent)

I have seen some changes in my ward as a result of education. I have a firm believer in my children that they will be great people. (A 30-year-old parent)

Education is very important because I am going through a lot of stress because of my low education level. (A 28-year-old parent)

Also, in finding out from the parents whether their level of education affected their children's education, parents were interviewed. Some parents admitted that they have a low level of education. Pertaining to parents' educational level and its effect on their children's academic performance here are some of their responses:
Yes, my level of education affects my involvement in my ward's academics. I cannot read nor write so always his elder siblings assist him in his homework. (A 31-year-old parent)

Teachers also shared their views on parents' educational level and the academic performance of their children these are some of the responses:

\begin{abstract}
The education level "de3" it does influence student academic performance. Most of the parents are illiterate so probably they don't even have any interest in the education system of pupil's life. What they are going to say is that they didn't have the chance to go to school so they have given you the chance and at least...... Probably are even farmers, what is their income? And they are forcing you to go to school and don't care. When their wards don't come to school, they don't care. So educationally, the parents' educational background is very poor hence do not influence their wards in anyway. (A 31-year-old teacher)
\end{abstract}

Although parents showed support for their children and were optimistic about the impact education would have on their children, the teachers in Kwaprow Basic School argued that most parents have shown limited interest in their pupils' educational progress. The above narratives show that the educational level of parents is not associated with the academic performance of pupils. This is also supported by the chi-square test (Table 6).

\subsection{Family Size of Pupils}

This section is aimed at identifying how the family size of pupils influences their academic performance. As a result, the researchers used some indicators to assess the kinds of support they receive from their parents. This is displayed in Table 7.

These indicators included; attention parents give to their children, parents' ability to provide for their children and the extent to which larger family size influences academic performance. The data in Table 7 indicated that the majority of pupils were of the view that their parents 
Table 7: Family Size and Academic Performance.

\begin{tabular}{|c|c|c|c|c|c|}
\hline Statements & $\begin{array}{l}\text { Never } \\
\mathrm{n}(\%)\end{array}$ & $\begin{array}{l}\text { Sometimes } \\
\mathrm{n}(\%)\end{array}$ & $\begin{array}{l}\text { Always } \\
\mathrm{n}(\%)\end{array}$ & $\begin{array}{l}\text { No Response } \\
\text { n (\%) }\end{array}$ & Mean \\
\hline My parents give me enough attention & $9(7.5)$ & $45(37.5)$ & $66(55.0)$ & - & 2.48 \\
\hline $\begin{array}{l}\text { My parents are able to provide all the things I need } \\
\text { for school }\end{array}$ & $3(2.5)$ & $35(29.2)$ & $81(67.5)$ & $1(0.8)$ & 2.63 \\
\hline $\begin{array}{l}\text { My parents are able to provide all the things my } \\
\text { siblings need for school }\end{array}$ & $2(1.7)$ & $42(35.0)$ & $76(63.3)$ & - & 2.62 \\
\hline $\begin{array}{l}\text { I am not able to get what I need for school because I } \\
\text { have a lot of siblings }\end{array}$ & $59(49.2)$ & $43(35.5)$ & $18(15.0)$ & - & 1.66 \\
\hline $\begin{array}{l}\text { My parents give me attention because I don't have a } \\
\text { lot of siblings }\end{array}$ & $53(44.2)$ & $27(22.5)$ & $40(33.3)$ & - & 1.89 \\
\hline $\begin{array}{l}\text { I am worse off in class because I have a larger family } \\
\text { size }\end{array}$ & $80(66.7)$ & $20(16.7)$ & $19(15.8)$ & $1(0.8)$ & 1.48 \\
\hline Average mean & & & & & 2.12 \\
\hline
\end{tabular}

Source: Fieldwork, Darko-Asumadu and Sika-Bright (2019)

get enough time for them. Approximately, 68 percent of the pupils said their parents are able to provide all the things they need for school. Similarly, 63.3 percent agreed that their parents are able to provide for the things their siblings need for school. While about 49 percent of the pupils were not able to receive school essentials, 44.2 percent received little attention from parents because they have a lot of siblings. This support Lacovou's (2001) argument that pupils receive less attention from parents because of the large number of siblings. Furthermore, approximately 67 percent of pupils said they were not worse off in class because of their large family size.

The relationship between the number of sibling influences and academic performance was further conducted to ascertain the significant difference between these variables. Thus, the study sought to establish a relationship between the number of siblings of pupils and the attention their parents give to them. Table 8 shows a correlation between the number of siblings and pupils' academic performance.

It can be deduced that there is a strong negative correlation between number of siblings and the academic performance of pupils. This is in line with Lacovou's (2001) claim that children from larger families are found to do worse than children from smaller families. From the descriptive data in Table 7, the majority of pupils were not able to get access to their basic needs for school which was attributed large family size. This is confirmed by the correlation model as the coefficient of $-0.722^{\star \star}$ implied that the larger the number of siblings, the lower the academic performance of pupils. This is partly due to the fact that they do not receive the needed attention from their parents. This finding agrees with that of Rouse and Barrows (2006) who purported that more attention is given to children from smaller families as compared to children from large families. The finding of the present study also confirms the comment that family size plays an important role in pupils' academic performance (Afful, 2014).

Interviews on how family size affects their children's education as they climb the educational ladder provided some responses.

I am managing to provide for my children and I know God will
show me His mercy as they climb high in education. I have four
children and I struggle to provide the needs for school but with
hmmmm.... With God we will survive. (a 34-year-old parent)
All depends on monetary terms and management. (a 38-year-old
parent)

Some of the teachers were also asked how they see the family size of pupils affects their academic performance. They explained:

\footnotetext{
Most of the parents gave birth early and they stopped schooling. Some also gave birth to plenty children and they have very low sources of income. When your basic needs are not provided for you how do you get a conducive environment to learn? (a 42-yearold teacher)
}

Most of the teachers had similar views that the family size has negative effects on the academic performance of the pupils. While some parents admitted that large family size affects the academic performance of pupils as they climb 
Table 8: Number of Siblings and Pupils Academic Performance.

\begin{tabular}{llll}
\hline & & $\begin{array}{l}\text { Total } \\
\text { performance }\end{array}$ & $\begin{array}{l}\text { Number of } \\
\text { Siblings }\end{array}$ \\
\hline $\begin{array}{l}\text { Total } \\
\text { performance }\end{array}$ & Pearson & 1 & $-0.722^{\star \star}$ \\
& Sig. (2-tailed) & & 0.028 \\
& $\mathrm{~N}$ & 120 & 120 \\
$\begin{array}{l}\text { Parent's } \\
\text { support }\end{array}$ & Pearson & $-0.722^{\star \star}$ & 1 \\
& Sig. (2-tailed) & 0.028 & \\
& $\mathrm{~N}$ & 120 & 120 \\
\hline
\end{tabular}

**Correlation is significant at the 0.05 level (2-tailed)

Source: Fieldwork, Darko-Asumadu and Sika-Bright (2019)

the academic ladder, others were of the view that they are managing with that.

\subsection{Parental Involvement}

The study sought to ascertain how parental involvement influences academic performance of pupils. In this regard, the researcher used indicators such as; the help parents provide; parents attendance to PTA meetings; parents encouragement, among others to measure how parental involvement influences academic performance. In addition, the researcher calculated the mean values for each variable to know the extent of the pupils' view on how parental involvement influences their academic performance.

From Table 9, the majority of pupils $(90.8 \%)$ said their parents encouraged them to learn. 84.2 percent of the pupils also said that, their parents make the best decisions for them. Moreover, 15 percent of the pupils said that their parents don't help them to their homework. While 37.5 percent said their parents help them to do their homework. Also, 8.3 percent of the respondents said their parents do not ask them about things that happened in school. Forty-five percent indicated that their parents ask them about things that happened in school. This confirms Walberg's theory of educational productivity which posits that educated parents can provide an environment that is best for the academic success of their children. This therefore supports our finding that parents support can affect their children's academic performance (Marzano, 2003). The data distribution showed that the majority of pupils said their parents encouraged them to learn and take the best decisions for them. This affirms Nadenge's
(2015) assertion that students whose parents are involved in their education guide them in making the right choices as well.

Also, 47.5 percent of the students said their parents sometimes help them in doing their homework. However, this finding contradicts with Oslen and Fuller's (2010) findings who said parents consistently helped them complete their homework. 90.8 percent, representing a very large majority of the students, said their parents encourage them to learn. It can be concluded from the above findings that parents encourage their children concerning their education and this finding further supports the work of Baidoo-Anu (2017) who said parents encourage their ward's concerning their education.

From this analysis, the mean scores of 2.88, 2.79 and 2.78 exceed the average mean of 2.43 . The highest mean of 2.88 indicates that, the majority of pupils' parents always encourage them to learn.

In response to the interview question that sought to find out the influence of parental involvement on the student's academic performance, several parents were asked about the essence of attending PTA meetings and these are the answers they had to say:

It is important because if the teachers are facing any challenges, they have to call the parents so that we reason together. (A 31-year-old parent)

It is very necessary for the parents and teachers alike. I attend PTA meetings most times if I can't make it, my wife represents me. I ask questions concerning the welfare of my wards. (A 55-year-old father)

A glance at the responses showed that most of the parents said its essential to attend PTA meetings and they do go. Parents revealed they go for the PTA meetings because they see it as a platform for them to discuss with the teacher's issues concerning pupils and the school as a whole. This corresponds to the responds from the pupils that their parents come for PTA meetings. Also, some teachers were asked how they see parents' attitude towards attending PTA meetings and their understanding of it and these are some of their responses:

Very poor. On my side very poor. They don't know the essence of PTA itself. With the particular community we are in, most of the parents do not understand why they should come to PTA meeting. Probably they feel like whatever that would be discussed here is not really important. They just come and listen and go away. (A 31-year-old teacher)

A critical assessment of the data showed that the majority of pupils said their parents attended PTA meetings. 
Table 9: Parental Involvement and Academic Performance.

\begin{tabular}{lllll}
\hline Statements & No & Yes & Sometimes & Mean \\
\hline My parents help me to do my homework & $\mathbf{N = 1 2 0 ( \% )}$ & $\mathbf{N = 1 2 0 ( \% )}$ & $\mathbf{N = 1 2 0 ( \% )}$ & \\
My parents come for PTA meetings & $18(15)$ & $57(47.5)$ & $45(37.5)$ & 2.23 \\
My parents encourage me to learn & $5(4.2)$ & $16(13.3)$ & $99(82.5)$ & 2.78 \\
My parents make best decisions for me & $3(2.5)$ & $8(6.7)$ & $109(90.8)$ & 2.88 \\
My parents beat me when I don't do well in my exams & $34(28.3)$ & $41(34.2)$ & $45(37.5)$ & 2.79 \\
My parents ask me about things that happen in school & $10(8.3)$ & $56(46.7)$ & $54(45.0)$ & 2.36 \\
My parents visit my class teacher constantly & $38(31.7)$ & $63(52.5)$ & $19(15.8)$ & 1.84 \\
\hline
\end{tabular}

Source: Fieldwork, Darko-Asumadu and Sika-Bright (2019)

Table 10: Pearson Correlation of Different Activities of Parental Involvement.

\begin{tabular}{|c|c|c|c|c|c|c|c|c|c|}
\hline & & & 1 & 2 & 3 & 4 & 5 & 6 & 7 \\
\hline \multirow{2}{*}{1} & \multirow{2}{*}{ My parent helps me academically } & CC & & 0.215 & 0.288 & 0.235 & 0.018 & 0.002 & 0.091 \\
\hline & & Sig. & 1 & 0.019 & 0.001 & 0.01 & 0.848 & 0.981 & 0.321 \\
\hline \multirow[t]{2}{*}{2} & \multirow{2}{*}{$\begin{array}{l}\text { My parents visit my class teacher } \\
\text { regularly }\end{array}$} & $\mathrm{CC}$ & & & 0.152 & 0.143 & 0.161 & 0.150 & 0.232 \\
\hline & & Sig. & & 1 & 0.097 & 0.119 & 0.079 & 0.102 & 0.011 \\
\hline \multirow[t]{2}{*}{3} & \multirow{2}{*}{$\begin{array}{l}\text { My parents ask about issues that } \\
\text { happen in school }\end{array}$} & $\mathrm{CC}$ & & & & 0.171 & 0.116 & 0.191 & -0.005 \\
\hline & & Sig. & & & 1 & 0.062 & 0.207 & 0.037 & 0.953 \\
\hline \multirow[t]{2}{*}{4} & \multirow{2}{*}{$\begin{array}{l}\text { My parent beat me when I don't } \\
\text { do well }\end{array}$} & $\mathrm{CC}$ & & & & & 0.243 & -0.006 & -0.119 \\
\hline & & Sig. & & & & 1 & 0.642 & 0.944 & 0.196 \\
\hline \multirow[t]{2}{*}{5} & \multirow{2}{*}{$\begin{array}{l}\text { My parent takes the best } \\
\text { decisions for me }\end{array}$} & $\mathrm{CC}$ & & & & & & 0.124 & 0.352 \\
\hline & & Sig. & & & & & 1 & 0.179 & 0.000 \\
\hline \multirow[t]{2}{*}{6} & \multirow{2}{*}{$\begin{array}{l}\text { My parents encourage me to } \\
\text { learn }\end{array}$} & $\mathrm{CC}$ & & & & & & & 0.179 \\
\hline & & Sig. & & & & & & 1 & 0.051 \\
\hline \multirow[t]{2}{*}{7} & My Parents come for PTA & $\mathrm{CC}$ & & & & & & & \\
\hline & Meetings & Sig. & & & & & & & 1 \\
\hline
\end{tabular}

Correlation is significant at the 0.05 level (2-tailed)

Source: Fieldwork, Darko-Asumadu and Sika-Bright (2019)

However, the teachers expressed contradictory views lamenting on parents' poor attendance to PTA meetings due to the nature of their jobs. Nadenge (2015) found out that most of the students appreciated it when their parents got involved in their school activities.

To examine whether parental involvement is significant in the academic performance of pupils in Kwaprow Basic School, the study used the Pearson Product Moment Correlation to establish relationship between the seven different types of parental involvement.
The correlation coefficient for all the seven different types of parental involvement is presented in Table 10.

It can be seen from the data distribution that the pupils at Kwaprow Basic School stressed the fact that their parent's visit to their class teacher to discuss their academic progress helped them academically (sig. $=0.0019$ ). Similarly, parents' discussion with their children concerning issues that happened that school (sig. $=0.001$ ) and the fact that their parents sanctioned them (in a form of beating) them whenever they performed 
Table 11: Parents Involvement and Pupils Academic Performance.

\begin{tabular}{llll}
\hline & & $\begin{array}{l}\text { Total } \\
\text { performance }\end{array}$ & $\begin{array}{l}\text { Parent's } \\
\text { support }\end{array}$ \\
\hline $\begin{array}{l}\text { Total } \\
\text { performance }\end{array}$ & Pearson & 1 & $0.626^{\star *}$ \\
& Sig. (2-tailed) & & \\
& $\mathrm{N}$ & 120 & 0.045 \\
& Pearson & $0.626^{\star *}$ & 120 \\
$\begin{array}{l}\text { Parent's } \\
\text { support }\end{array}$ & Sig. (2-tailed) & 0.045 & \\
& $\mathrm{~N}$ & 120 & 120 \\
\hline
\end{tabular}

${ }^{* *}$ Correlation is significant at the 0.05 level (2-tailed)

Source: Fieldwork, Darko-Asumadu and Sika-Bright (2019)

poorly (sig. $=0.01$ ) aided their academic progress. However, parents' involvement in the child's decision-making, encouragement to learn and attending PTA meetings were not statistically significant to aiding pupils' academic progress.

The study showed that the relationship between the overall model on parental involvement and academic performance of pupils was significant. Table 11 depicts the performance of pupils in the first row against parents' education background in the second column where the two variables meet gives the correlation coefficient (cc) of $0.626^{\star \star}$, its p-value, Sig. (2-tailed) is 0.0045 and N (sample size) is 120 .

The correlation coefficient of $0.626^{\star \star}$, between the performance of pupils and the parental support of child's education is significant at the 0.05 level. In other words, the probability that pupils' academic performance will improve when they receive support from the parent is true. The coefficient of $0.626^{\star \star}$ showed a moderately positive relationship between the parental support to child's education and academic performance. This also means that if parents encourage their children to learn, they are more likely to perform. This finding avers with Altschul's (2012) assertion that parental involvement including their encouragement has a direct link with the students' academic successes. This can be linked to Walberg theory of educational productivity which states that the academic performance of students heavily depends upon the parental involvement in their academic activities to attain a higher level of quality in academic success (Barnard, 2004).

\section{Conclusions and Recommendation}

The study concluded that parental involvement in their children's education was very important to their children's academic performance. Family size of pupils also negatively affected their academic performance in the sense that pupils did not only lack the basic necessities that could help them improve academically, but also received little attention from their parents. Parents' educational level did not affect academic performance of pupils although the study revealed that some parents could not assist them with their homework, reading and learning. Some parents failed to attend Parent-Teacher Association meetings to enquire more about their children's performance at school. This could be largely attributed to the fact that most of these parents had a low educational level, and so did not see the relevance of attending such meetings. The occupation of parents significantly affected the academic performance of pupils. This implied that pupils' performance largely depended on their parent's occupation granted their parents were involved in their academic work. Aside the level of education of parents, parental occupation, family size and their involvement significantly influenced the academic performance of pupils at Kwaprow Basic School. It is therefore recommended that the PTA should organize meetings and programmes to educate the parents on the need to get involved in their wards' education so as to aid them perform better academically.

Conflict of Interest: Authors state no conflict of interest.

\section{References}

Adane, L. F. (2013). Factors affecting low academic achievement of pupils in Kemp Methodist Junior High School in Aburi, Eastern Region (Doctoral dissertation). University of Ghana: Accra.

Adler, A. (1931). Theory and practice of counselling and psychotherapy ( $8^{\text {th }}$ edition). CA: Thomson Brooks/Cole.

Afful, S. O. (2014). Socio-economic background and academic performance of children in basic schools in Asikuma-OdobenBrakwa District, Ghana (Doctoral dissertation). University of Education, Winneba: Winneba.

Akanle, O. B. (2007). Socio-economic factors influencing student's academic performance in Nigeria. Some explanation from a local survey. Retrieved from www.medwelljournals.com/ abstract/?doi=pjssci.2008.319

Altschul, I. (2012). Linking socio-economic status to the academic achievement of Mexican American youth through parent involvement in education. Journal of the Society for Social Work \& Research, 3(1), 13-30. 
Amazu, N. A. \& Okoro, C. C. (2015). Advances in research: Social status of parents and student's academic performance in aba educational zone, Abia State: University of Uyo, Nigeria.

Bakken, A. (2003b): Mother tongue teaching and school achievement. Tidsskrift for ungdomsforskning, 3(1), 3-23.

Barnard, W. M. (2004). Parent involvement in elementary schools and educational attainment. Children and Youth Services Review, 26, 39-62.

Barry, J. (2006). The effect of socio-economic status on academic achievement. Wichita State University: Wichita State.

Beller, E. (2008). Bringing intergenerational social mobility research into the 21st Century: Why mothers matter. Berkeley: University of California.

Brown, M., McNamara, G., O’Brien, S., Skerritt, C., O'Hara, J., Faddar, J., ... \& Kurum, G. (2020). Parent and student voice in evaluation and planning in schools. Improving Schools, 23(1), 85-102.

Chenz, Z., \& Liu, R. X. (2014). Comparing Adolescent only children with those who have siblings in academic related outcomes and psychosocial adjustment. Child development research. Retrieved from http://www.dx.doi.org/10.1155/2014

Cooter, K. S. (2006). When mama can't read: Counteracting intergenerational illiteracy. The Reading Teacher, 59(7), 698-702

Eamon, M. K. (2005). Social demographic, school, neighbourhood, and parenting influences on academic achievement of Latino young adolescents. Journal of Youth and Adolescence, 34(2), 163- 175.

Epstein, J. L., Sanders, M. G., Simon, B. S. \& Salinas, K. C. (2002). School, community, and community partnerships: Your handbook for action (2nd Edition). Thousand Oaks, CA: Corwin Press.

Ghana Statistical Service (2015). 2015 Labour Force Report. Retrieved from www.2.statsghana.gov.gh

Graetz, J. (2006). The impact of parents' background on their children's education. Educational Studies 268. Saving Our Nation, Saving Our Schools: Public Education for Public Good.

Hassan, J. E. (2009). Parents' socio-economic status and children's academic performance. Report of Norwegian Social Research, NOVA Notat, 7(09).

Juma, S. O. (2016). Influence of parental socio-economic status on students 'academic performance in public secondary schools in Tana River County, Kenya. Unpublished Thesis

Kalil, A. (2005). Unemployment and job displacement: The impact on families and children. Ivey Business Journal, 2, 1-5.

Lacovou, M. (2001). Family composition and children's educational outcomes. Institute for Social and Economic Research, Essex University: UK.

Mallan, D. (2009). Relationship between socio-economic performance and students' academic performance of Senior Secondary Schools in Kebbi (Unpublished M.Ed. Dissertation). Usmanu. Danfodiyo University: Sokoto.

Marzano, R. J. (2003). What works in Schools: Translating research into action? Retrieved from http://pdonline.ascd.org/pdonline/whatworks/ marzano2003ch13.html

McNeal, R. B. (2001). Differential effects of parental involvement on cognitive behavioural outcomes by socio-economic status. Journal on Socio-Economics, 30(2), 171.
Mensah, M. K. (2013). Influence of parenting style on the social development of children. Academic Journal of Interdisciplinary Study, 2, 123-129.

Mudassir, A. \& Abubakar, N. (2015). The impact of parents' occupation on academic performance of secondary school students. Multilingual Academic Journal of Social Sciences, 3(1).

Muhammed, R. (2012). Impact of parents' profession on their children's learning English in Pakistan. International Journal of Learning \& Development, 2(1).

Nadenge, M. G. (2015). Relationship between parental socioeconomic status and student academic achievement: $A$ case study of selected schools in urban informal settlements in Westlands division, Nairobi County. University of Nairobi: Kenya.

Nannyonjo, H. (2007). Education inputs in Uganda: An analysis of factors influencing learning achievement in grade six. Washington DC: World Bank.

Okumu, I. M., Nakajjo, A., \& Isoke, D. (2008). Socio-economic determinants of primary school dropout: The logistic model analysis. Retrieved from http://mpra.ub.uni-muenchen. de/7851

Okwan, S. A. (2014). Socio-economic background and academic performance of children in basic schools in Asikuma-Odoben, Brakwa District, Ghana. University of Education, Winneba.

Orodho, J. (2009). Elements of education and social science research methods (2 ${ }^{\text {nd }}$ Edition). Maseno, Kenya Kanezja Publishers.

Oslen, G. \& Fuller, M. L. (2010). The benefits of parent involvement: what research has to say? Retrieved from https://www. education.com/reference/article/benefits-parent-involvement research/

Reeves, D. (2009). High performance in high poverty schools: 90/90/90 and beyond. Denver, CO: Center for Performance Assessment

Rouse, C. E., \& Barrow, L. (2006). U.S. elementary and secondary schools: Equalizing opportunity or replicating the status quo? The Future of Children, 16(2), 99-123.

Shah, M., Atta, A., Qureshi, M., \& Shah, H. (2012). Impact of socio economic status (ses) of family on the academic achievements of students. Gomal University Journal of Research, 28(1), 12-17.

United Nations (2006). The Millennium Development Goals Report (2006). Retrieved from https://wwww.un.org.

United Nations Children's Fund (UNICEF) (2014). For every child: The promise of equity a fair chance. Retrieved from https://www. unicef.org/publications/files/For every child a fair chance.pdf

United States Department of Education (2000). Confidence-Helping Your Child through Early Adolescence. Retrieved from http:// www.ed.gov/parents/academic/help/adolescence/part 8.html.

Walberg, H. J. (1981). A psychological theory of educational productivity. In F.H. Farley\& N. U. Gordon (Eds.), Psychology and education. Berkeley, CA: McCutchan. 